\title{
Vestida de noiva. Diferenciação e prestígio em disputa no mercado de festas de casamento*
}

\author{
Michele Escoura**
}

\section{Resumo}

Em 2015 o mercado brasileiro de festas de casamento movimentou $\mathrm{R} \$ 17$ bilhões. Neste artigo, coloco sob análise a relação entre noivas e os vestidos comercializados nesse setor de mercado. Sob perspectiva etnográfica, discuto dados produzidos em trabalhos de campo em Belém e São Paulo e mostro como os modelos de trajes têm demarcado estilos hierarquizados de feminilidade, ao mesmo tempo que o trânsito de noivas pelas lojas evidencia estratégias de diferenciação de classe. Por fim, argumento que valores de vestidos e de noivas se constituem mutuamente num processo de coprodução de distinção.

Palavras-chave: Casamento, Gênero, Consumo, Prestígio, Diferença.

" Recebido em 30 de junho de 2018, aceito em 21 de novembro de 2018.

** Doutora em Ciências Sociais pela Universidade Estadual de Campinas (Unicamp), Campinas, SP, Brasil. micheleescoura@gmail.com / http://orcid.org/0000-0002-8822-2032 
Dressed as a Bride. Differentiation and Prestige in Dispute in the Wedding Receptions Market

\begin{abstract}
In 2015 the Brazilian wedding receptions market reached $\mathrm{R} \$ 17$ billion and, in this article, I analyze the relationship between brides and the dresses offered by the sector. From an ethnographic perspective, I discuss data produced in fieldwork in Belém and São Paulo and show how the models of gowns have demarcated hierarchical styles of femininity, while the movement of brides through stores reveals strategies of class differentiation. In conclusion, I argue that the values of dresses and brides are mutually constitutive in a process of co-production of distinction.
\end{abstract}

Keywords: Wedding, Gender, Consumption, Prestige, Difference. 


\section{Introdução: entre vestidos e noivas}

"Eu não estou aqui vendendo bebida, estou vendendo o seu sonho. E quanto você quer pagar pelo seu sonho?" questionava um fornecedor de drinques para a noiva ao meu lado em uma das feiras voltadas para negócios na produção de festas de casamento. O episódio ocorria em 2015, mesmo ano em que o mercado especializado em eventos e cerimônias movimentava cerca de $\mathrm{R} \$ 17$ bilhões no Brasil. Desde lá, esta pesquisa de doutorado tem por objetivo compreender as relações mobilizadas no tempo de preparo de festas de casamento e como elas produzem contextos de aproximações, diferenciações e desigualdades. ${ }^{1}$

Os dados que aqui sustentam o texto etnográfico foram produzidos em diferentes frentes de trabalho de campo em Belém (PA) e São Paulo (SP). Durante o período de 2015 a 2017 acompanhei o cotidiano de diferentes lojas de aluguel e venda de vestidos de noiva em contrastantes polos econômicos da capital paulista. Nesses espaços pude produzir grande parte do material de observação participante que compõe a pesquisa e, ainda, conheci noivas e noivos que, posteriormente, participaram de entrevistas em profundidade, somando-se aos interlocutores de minha rede pessoal de contatos nos dois estados. ${ }^{2}$

1 Sob o título "Fazer festa é uma guerra. Relações entre vestidos, noivas, anfitriões e convidados na organização de casamentos", a tese foi defendida em 2019, no Programa de Doutorado em Ciências Sociais da Unicamp, contou com orientação da Profa. Dra. Isadora Lins França e financiamento Capes.

2 Entre as personagens que compõem este texto e aparecem sob nomes fictícios, Sofia, em Belém, e Gabriela, em São Paulo, foram duas noivas que conheci a partir do trabalho de campo sobre os contextos de produção e comercialização de vestidos de noivas. A primeira era a estilista de uma outra interlocutora e a segunda, a partir da mediação de seu noivo, ele sim cliente da loja de trajes a rigor onde fiz observação participante no bairro de São Mateus, extremo leste da capital paulista. Entre as duas, minha interlocução foi delimitada a momentos de entrevistas em profundidade. Já Camila e Helena faziam parte da minha rede pessoal e anterior à pesquisa. Sem restrições, ambas me permitiram acompanhar de perto a organização de suas festas de casamento e ofereceram uma interlocução que contemplou outras dimensões e níveis de profundidade $e$ 
Fazer um casamento é, sem dúvida, um extraordinário investimento financeiro, de energia e nas próprias relações (Miller, 2000). Mas é também um recorte temporal provocado pelos próprios sujeitos, extraordinário, em que o caráter cotidiano da vida é colocado em suspenso e no qual contornos de gênero, posições de classe e fronteiras familiares aparecem como efeitos iminentes dos conflitos.

$\mathrm{O}$ vestido de noiva é o elemento imprescindível que diferencia um casamento dos demais tipos de festa e não raro é o marco inicial do processo de organização desse evento. Sob uma aura de "magia" e constantemente descrito como um "sonho", o momento de escolha do vestido de noiva se mostra como uma etapa tão protocolar e cerimonial quanto o próprio casamento. $\mathrm{E}$, aqui, foi também uma oportunidade singular de colocar a relação entre noivas e o mercado especializado em casamentos sob análise.

Neste artigo, sistematizo os dados produzidos pela pesquisa entre 2015 e 2016. Percorro os diferentes espaços de atendimento de clientes, contraponho as variadas abordagens de venda, descrevo as duas principais modelagens do traje, destaco as tensões entre mães $e$ filhas e sigo os passos das noivas entre as cidades e pela cidade em busca do vestido ideal.

Analiso, de um lado, como o consumo de determinados estilos de vestidos que se deslocam entre os territórios marcados por referenciais econômicos posicionam noivas em diferentes versões de feminilidade $e$, de outro lado, como o trânsito de noivas pelos territórios marcadamente femininos das lojas, em contrapartida, é acionado como estratégia de reposicionamento de classe. E, como argumento principal, defendo que valores de vestidos e noivas de valor constituem-se mutuamente num

detalhamento do material empírico. Dada a proximidade afetiva e de confiança na nossa relação prévia, com elas eu pude ampliar as ocasiões de entrevista também para observações em campo, tanto durante suas interações com os profissionais do mercado como nas tensas negociações com seus familiares, como será visto a seguir. 
processo de coprodução de distinção, no qual valores econômicos e morais são intencionalmente combinados. ${ }^{3}$

\section{O escolhido, a escolhida}

"Não é a gente que escolhe o vestido, é o vestido que escolhe a gente" era o que dizia Gabriela sobre o momento em que decidiu qual vestido usar no dia de seu casamento, em 2015. Com celular em punho e passando pelas dezenas de fotos do casamento que tinha acontecido semanas antes, a jovem do Jardim Conquista, zona leste de São Paulo, se animava em mostrar aquele que tinha sido um dos itens mais caros de sua festa. Eduardo, o noivo, riu quando eu perguntei "como tava o vestido". Ele fez um sinal sobre seus peitos enquanto estufava a boca. Seu pai, evangélico, teria dito "pra que tudo isso?" em referência ao decote da nora entrando na cerimônia. Gabriela acompanhou a risada enquanto eu voltava a perguntar sobre o vestido e o noivo gargalhava novamente: "Caro! Caro!". Aí, ela interrompeu o riso, retraiu o rosto e intercedeu à provocação com um enfático "não foi caro, foi $\mathrm{R} \$ 2,5$ mil, foi super barato". ${ }^{4} \mathrm{Na}$ cor off-white, com pedras transparentes e brilhantes bordadas sobre as aplicações de renda, o vestido seguia um modelo cuja saia se armava sobre estruturas de enchimento, dando o efeito de afinar a

3 Uma primeira versão desse debate foi apresentada em 2016 no "SPG29 Sexualidade e gênero: corpos e identificações em trânsito", no $40^{\circ}$ Encontro Anual da ANPOCS, em Caxambu (MG), ocasião em que pude contar com as inspiradoras apreciações de Carolina Branco de Castro Ferreira, Isadora Lins França, Regina Facchini, Roberto Efrem Filho e Roberto Marques. Além delas e deles, agradeço também Bernardo Fonseca Machado, Bianca Briguglio, Bruno Terribas, Cristina Marins, Heloisa Buarque de Almeida, Julian Simões, Maria Filomena Gregori e Natacha Simei Leal pelas leituras e comentários ao longo do desenvolvimento desses argumentos, bem como a Carlos Filadelfo e Jamila Venturini pela generosa revisão deste texto final.

${ }^{4}$ Para efeitos de comparação, em 2015, o salário mínimo brasileiro era de $\mathrm{R} \$ 788,00$. 
cintura da noiva, o que é esperado pela maioria de minhas interlocutoras.

Meu vestido estava sujo, dentro do provador, que alguém tinha provado e tinha largado lá. A mulher trouxe quinhentos brancos e eu não queria. Não ficou bom, não era... A mulher tava frustrada já porque ela colocou a loja no provador e eu não queria nenhum. Aí que a menina olhou no vestido e falou "tem esse aqui...Vamos tentar?". "Ai, moça, nem quero mais", aí ela "por favor". A gente colocou. A hora que ela colocou, ela nem apertou, nem trançou, eu já falei "é esse!". Assim, ela só colocou o vestido, tava sujo, tava horrivel, o vestido tava até rasgado. Aí eu falei "é esse!". É inexplicável, é inexplicável. Aí eu coloquei o vestido, ela apertou, aí eu coloquei o sapato, aí eles te sentam, colocam o penteado, te dá o buquê... $\mathrm{E}$ coloca uma música de casamento mesmo, de entrada de casamento e, um espelho gigante, com a música de fundo, com o buquê, você fica ali se olhando e você fala: "meu, é isso, é esse!". Aí você já começa a chorar, porque passa um filme na sua cabeça, é inexplicável. Você não escolhe o vestido. Porque assim, você olha vários e fala "esse é bonito, é esse que eu quero", mas não... É o vestido que te escolhe (Gabriela, São Paulo, 2015).

Essa sensação de ser incontrolavelmente escolhida pelo vestido parecia a mesma experimentada por Helena que, no bairro do Jardins, do outro lado da cidade, buscava sua peça. Localizada em um casarão clássico da Avenida Rebouças, endereço símbolo dos tempos áureos do café que colocou São Paulo no coração financeiro no país, a loja era apenas uma dentre tantas especializadas no ramo de roupas de festas pela região. Lá, acompanhei a noiva e sua mãe durante toda a prova para a escolha do vestido. ${ }^{5}$

${ }^{5}$ No período de observação de campo, metodologicamente selecionei três diferentes espaços de comercialização de vestidos para realizar a análise: 1) uma 
No horário previamente agendado, como exigência do estabelecimento, chegamos $e$ fomos encaminhadas para os sofás da sala de espera. Um imponente lustre de cristais descia do teto $e$ iluminava a lareira que, naquele dia de calor, servia apenas para acomodar duas Barbies vestidas com réplicas em miniatura dos vestidos da última coleção da loja. Cinco minutos depois, uma moça nos chamou. Caminhamos para uma sala ainda no piso térreo do casarão, onde estavam dispostas lado a lado duas mesas de madeira e Danilo, o estilista selecionado durante $\mathrm{o}$ agendamento.

$\mathrm{O}$ início do atendimento parecia uma entrevista. Ele e Bianca, sua assistente ${ }^{6}$, descarregaram uma bateria de questões: quem de nós éramos a noiva, o que éramos umas em relação às

loja de bairro de aluguel de trajes a rigor em São Mateus, localizada num dos principais endereços de comércio popular da zona leste paulista (a Avenida Matteo Bei) e frequentada essencialmente por moradores da região, clientes vindos dos populosos bairros de trabalhadores migrantes do norte e nordeste, fundados no último século a partir de ocupações irregulares e conjuntos habitacionais estatais; 2) a conhecida "Rua das Noivas" no centro da capital, que faz parte de uma região comercial onde está também a Rua 25 de Março e por onde circulam diariamente milhares de pessoas, muitas delas, inclusive, vindo de outras cidades e estados brasileiros em busca dos bons preços divulgados em grande medida pelos mercados informais locais; 3) uma loja na centenária Avenida Rebouças que, em conjunto com os dados trazidos pelas noivas entrevistadas, confere materialidade ao mercado disposto na região dos Jardins, um conjunto de bairros caracterizados por seus imóveis com os mais elevados valores de metro quadrado da cidade, predominantemente residenciais, com paisagens arborizadas e especial aderência de negócios de bens e serviços voltados às elites econômicas e culturais, de lojas de carros importados a restaurantes internacionalmente conceituados.

${ }^{6}$ Em outro contexto, discuto as diferentes dinâmicas de gênero no atendimento dos profissionais do mercado procurando dar destaque ao contraste entre a loja do Jardins, onde há apenas estilistas homens, e a de São Mateus, com todas profissionais mulheres. Da contraposição dos espaços de negócios onde, de um lado, o gênero do estilista contribui para a avaliação de maior profissionalismo e, de outro lado, "a mulherada manda em tudo" se torna uma bandeira de autoafirmação, aponto para as nuances provocadas pela intersecção entre gênero e classe (Escoura, 2017). 
outras, qual a data do casamento, o horário da cerimônia, se seria em igreja ou em local aberto e também o número de convidados. $\mathrm{Na}$ ocasião, fui apresentada como uma "amiga" e a menção de que fazia uma "pesquisa sobre casamentos" não pareceu gerar qualquer atenção entre os profissionais que só tinham olhos para a possivel cliente.

Helena se encolheu, constrangida, quando o estilista levantou com uma fita métrica em punhos para tirar suas medidas. Avaliava que estava um pouco acima do peso, mas tinha confiança que emagreceria até a data da festa, dali a um ano. Ele a tranquilizou, disse que outras provas seriam feitas até o evento $e$ que havia ainda muitas estratégias de ajustes da peça no corpo: "para a barriga a gente dá um jeito, coloca calcinha da noiva, uma barbatana...", disse se referindo a uma espécie de calcinha com uma cinta de compressão $e$ às estruturas de metal que são costuradas no interior do forro do vestido de modo a prensar $e$ modelar a cintura de quem o usa. Já sobre o temor de sentir muito calor durante o casamento, uma vez que ansiava por um modelo "clássico" de mangas longas, o profissional não amenizou: "noiva é foto, é estilo. Tem que pensar em como você quer se ver na foto do seu casamento 10 anos depois", disse em argumento aos sacrifícios que deviam ser feitos naquele momento marcado para ser extraordinário.

Finalizada a conversa inicial, subimos todas para uma sala de provas no segundo piso do casarão e esperamos Danilo voltar com os trajes. Lá, cada noiva era atendida em um quarto privado, recoberto por um carpete bege e com duas paredes, uma de frente a outra, inteiramente revestidas por espelhos e de onde saíam focos de luzes direcionados a um pedestal. Responsável pela troca de roupas, Bianca esperou a noiva se despir e depois equilibrou sobre Helena um vestido no estilo evasé, cujo caimento deixava marcado o corpo apenas até a cintura para depois se abrir em uma saia rodada. Em seguida aos botões fechados e às mangas compridas em renda ajustadas por alfinetes, Danilo retornou a sala de prova e mostrou-se animado com o que via. "Você é muito clássica, isso deve ser de casamento em vida passada", ponderou 
enquanto improvisava um topete seguido de um coque no cabelo de Helena. "Deixa eu montar ela", dizia colocando primeiro um véu branco e longo saindo do meio do penteado e, depois, ajeitando a calda e o buquê em punhos pela cliente. Sob o pedestal, iluminada, Helena parecia pronta para o casamento. E, ansiosa, viu no reflexo do espelho a porta do quarto ser aberta $e$ sua mãe, chorosa, vir ao encontro de sua imagem vestida de noiva.

As pedrarias bordadas no vestido cintilavam a cada vez que a cliente se movia diante das luzes em sua direção. O estilista percebeu que o vestido tinha caído no gosto e começou a valorizá-lo: "imagina essa manga longa aí na foto colocando a aliança, aparece o preto e branco da roupa do noivo e a renda branca da noiva, fica lindo". A mãe da noiva, orgulhosa, via a filha e ressaltava as qualidades da roupa que, em seus termos, não era como um vestido "sereia" que "parece coisa daquelas mulheres que casam com os velhos, e querem dar golpe do baú". O estilista ria, e completava: "parece piriguete tentando ficar fina, não é?".

Helena tinha gostado do vestido, mas ainda não parecia satisfeita - ou talvez tivesse curiosa para ver como ficariam os outros modelos. Mais vestidos foram solicitados $e$ as trocas continuaram a ponto de o coque já parecer desfeito e Danilo desanimar com o atendimento. Entretanto, horas depois, nem o cansaço e nem o descabelo foi capaz de diminuir o efeito de surpresa e encantamento quando Helena finalmente experimentou o vestido "sereia" trazido à revelia da ideia original.

Justo em seu corpo até abaixo do quadril, com um decote mais acentuado e mangas longas desenhadas por uma renda em arabesco, o vestido fez a noiva lacrimejar. O estilista nem tinha terminado de fazer os ajustes ao corpo com os alfinetes e Helena já pedia para colocar também o véu. "Amei! Amei!" dizia ela antes de abrir a porta para a mãe entrar novamente e ver aquele que era, naquela altura, algo como o décimo vestido que provava.

"É mãe, o olho dela encheu de lágrima... Acho que ela é 'sereia', acho que ela quer dar golpe no velhinho..." dizia o 
estilista em tom de piada. A mãe estava visivelmente frustrada $e$ Bianca tentava remediar a situação: "toda mãe quer ver a filha que nem 'princesa', né?", dizia em referência aos primeiros vestidos provados. "Eu quase chorei no primeiro, parecia uma menininha", disse antes de completar com um: "mas é você quem sabe" para a filha.

Danilo ponderou. "Minha linda", referiu-se novamente à noiva, "você tem que se sentir realizada. Vai olhar seu álbum daqui vinte anos e tem que se sentir realizada". Helena ouvia todas as falas enquanto olhava-se fixamente entre as duas paredes de espelho. Destacava positivamente a renda que cobria seus braços e o arabesco nas suas costas em uma tentativa de ganhar o apoio da mãe. Ao mesmo tempo seu discurso já mudava de tom, "no outro eu parecia uma santa!" zombava.

"Para uma noiva, as palavras são muito importantes. O primeiro, quando eu perguntei se você gostou você disse 'adorei'. Agora você disse 'amei!'”, dizia Danilo ao sugerir que a busca pelo vestido teria terminado. Helena concordou $e$, ao perguntar o preço, teve como resposta a orientação de que aquilo era assunto "lá pra baixo', em referência ao piso térreo do casarão.

A noiva foi desmontada. Aos poucos a jovem de 25 anos ia ressurgindo de blusinha colorida e shorts jeans. Descemos todas e dessa vez fomos para uma mesa em outro ambiente, mais próximo da sala de entrada e da presença dos outros funcionários. Em um papel, Danilo escreveu o valor do vestido: $\mathrm{R} \$$ 9,6 mil para um primeiro aluguel e $\mathrm{R} \$ 5,9$ mil para o segundo. ${ }^{7}$ As clientes se entreolham tensas. Era muito mais do que os $\mathrm{R} \$ 3$ mil imaginados

\footnotetext{
7 A cada ano, os estilistas da loja elaboram diferentes modelos que irão compor a coleção da temporada e, depois do lançamento em grandes eventos na cidade, os modelos ficam disponíveis nos armários da loja (acessados apenas pelos funcionários). Cada peça confeccionada é alugada no máximo duas vezes, sendo mais caro o aluguel daquela até então nunca usada. Bianca me explicou que depois do segundo aluguel, os vestidos são revendidos para lojas menores ou do interior do estado, o que parece sugerir uma cadeia de circulação desses objetos em diferentes lugares e classes sociais.
} 
e combinados como parte do presente de casamento de mãe para filha. "Ainda tem que alugar o véu, o sapato, a coroa... Nisso ainda vai mais uns $\mathrm{R} \$ 1,5$ mil", pensava alto a noiva com o intuito de virar a situação. Nada feito. Frustração. Não havia outra saída senão subir novamente pelas escadas e recomeçar a busca, agora focando no modelo mais parecido possível com aquele escolhido, mas de coleções anteriores, mais baratas.

Voltamos ao quarto de provas e Danilo estava visivelmente desanimado enquanto improvisava os ajustes num modelo muito maior do que o corpo da cliente. "É renda chantilly francesa" dizia a assistente numa tentativa de valorização da peça alfinetada para ficar mais "sereia" e dar algum novo ânimo à noiva ao ver seu corpo novamente ganhando opulência. Na negociação entre estilo e preço, sua mãe parecia também um pouco mais satisfeita: apesar de sereia, a renda cobrindo o colo e os braços da nova peça parecia atribuir mais seriedade ao modelo. Por $\mathrm{R} \$ 3,5$ mil e sem lágrimas de emoção, o contrato foi finalmente fechado. Porém, dois dias depois da longa jornada de provas, mais novidades vieram por um aplicativo de mensagens instantâneas:

\section{Mensagem de texto:}

Troquei de vestido! KKKKKKKK.

Sou uma noiva FELIZZZZ

Nossa, eu tô me sentindo mto aliviada!

\section{Mensagem de áudio:}

Voltei lá! Aí cheguei lá, tinha avisado ele antes que eu tava insegura e marquei horário. Aí cheguei e falei, bom, vou provar primeiro o que eu fechei, pra não poluir minha cabeça. Quero ver como eu realmente fico nele. Aí deixaram bem justinho, do jeito que eu queria, tal. Aí eu olhava... Fiquei com ele uns 20 minutos com ele no corpo, olhando.... Vendo como que eu me sentia. Eu me sentia "ok". Aí eu falei, bom vamos pôr o outro. Aí não deu. Na hora que eu pus o outro, sei lá véio, é um negócio! Eu me senti tão bonita, tão poderosa nele, sabe? Que eu falei "não adianta eu ficar com um e gostar mais do outro". A minha mãe é super preconceituosa, falou que era um vestido que 


\begin{abstract}
a Valesca Popozuda usaria. Mas a Valesca Popozuda não usaria o de renda Chantilly francesa, desse jeito. Aí eu falei "mãe, não adianta ser preconceituosa, eu vou fazer o que eu me sinto bem, como eu me senti melhor". Esse que eu gostei mais, que eu fechei agora, eu falei pra ela... Ela falou "ah, você precisa emagrecer para usar ele". Mas eu posso casar amanhã, do jeito que eu tô, gorda do jeito que eu tô, que eu me senti linda, me senti muito bonita, me senti elegante, não me senti vulgar... E tô feliz, sabe? Muito feliz! (Helena, São Paulo, 2015).
\end{abstract}

De volta à loja no horário de serviço, Helena tinha renegociado o preço do primeiro vestido "sereia" e conseguido parcelar em 5 vezes no cartão de crédito a diferença entre o modelo mais caro e aquele pago por sua mãe. Ao final, o vestido que a tinha feito se sentir "poderosa" entrava no seu campo de possibilidades.

Já, em Belém, Sofia queria se sentir "princesa". "Pra mim não existe nada mais feminino do que renda, e ela usa em todos os vestidos dela" dizia a noiva enquanto justificava o porquê de ter escolhido a estilista Lethicia Bronstein ${ }^{8}$ e seu atelier nos Jardins, em São Paulo, para confeccionar seu vestido de noiva após ter passado pela loja de outro estilista famoso.

A sala dela é uma casinha de boneca, é uma sala de
princesa. É rosinha com azul bebê e coraçõezinhos,
coroinhas. E ela não faz só noivas, ela faz moda festa. Por
isso que te digo, toda mulher que se arruma para uma
grande festa quer ser uma princesa. Tinha uma cadeira,
uma poltrona de rainha, muitas fotos de celebridades
vestindo os vestidos dela. E ela tem uma coisa que eu

8 Estilista carioca, com loja apenas em São Paulo e de uma nova geração de profissionais ligados à moda de festas. Começou a ganhar maior notoriedade na década de 2010 quando passou a produzir peças exclusivas para mulheres reconhecidas da TV brasileira, além de vestidos de noivas usados como figurinos de importantes telenovelas. 
também gosto muito, ela usa muita renda (Sofia, Belém, 2016).

A jovem, de 32 anos, havia se casado na capital paraense em junho de 2016 e, em seguida, aberto um atelier de vestidos de noivas na cidade natal. Quando a entrevistei em seu escritório, a conversa girou em torno dos vestidos a partir tanto de sua experiência como noiva como sua visão enquanto estilista.

Seu vestido, ao lado do buffet, entrou como item em que ela não buscou fazer nenhuma economia na hora de organizar seu casamento. Confeccionado a partir da sobreposição de três tipos diferentes de rendas, o traje se transformava ao longo da noite. Em sua entrada na igreja, a noiva apareceu com um modelo de vestido todo fechado no busto. O colo e os braços foram cobertos por uma das rendas floridas aplicada sobre um tule branco. $\mathrm{O}$ vestido seguia justo até o meio da coxa, de onde se abria uma anágua e a saia com uma cauda. Mas, ao final da cerimônia, o vestido se transformou criando a sensação de ter sido trocado por outro modelo: sem as mangas, o trecho de renda que cobria o decote nos seios e o volume do saiote, a noiva chegou no salão de festas com uma peça decotada e justa pelos contornos de seu corpo.

Mostrando as fotos do seu casamento publicadas em uma rede social, ela me dizia que sua festa seguiu um "estilo romântico", embora ela não se considere uma pessoa tão romântica. Para ela, se vestir como noiva foi como entrar em uma personagem: ela não queria que o vestido fosse uma materialização de sua personalidade, mas de como ela queria se sentir naquele dia do casamento, e só nele:

O vestido é um "RG" de um sonho, que não necessariamente é a personalidade da noiva. Eu posso ter meu sonho de princesa, mas ser uma mulher super moderna, atual, durona e tal... Mas, lá dentro, eu tenho o sonho de um dia ser princesa e aquele vestido vai ser a materialização de alguma coisa ali que não necessariamente é minha personalidade. Por exemplo, eu não sou 
romântica. Eu sou muito resolvida, prática. Mas na hora de casar, eu fui. Por quê? Porque eu tenho uma história assim, principalmente com as princesas, que eu era apaixonada pelas princesas. E aí de algum lugar veio isso e eu disse "não, quero casar de princesa, vou casar princesa". Tanto que minhas amigas quando me viram na igreja, elas assim "jamais imaginava que tu ia casar desse jeito". Não é minha personalidade, não é a Sofia que eu mostro pra todo mundo. Dificilmente a noiva casa do jeito que ela é no dia a dia (Sofia, Belém, 2016).

Ela queria "ir para a igreja mais fechada", "mais composta", com "uma coisa mais sóbria". Ao mesmo tempo, "casar princesa" era também a expectativa de seu noivo que, assim como a mãe de Helena, não fez questão de esconder sua preferência a um modelo específico de vestido: "ele que me queria princesa. Ele só falava assim "não quero você sensual na igreja, não quero, quero você noiva"".

Sofia, ao contrário de Helena e Gabriela, não alugou seu vestido. Para ela a escolha de sua peça para o casamento não estava relacionada à sensação de se sentir escolhida, mas de escolher e construir com a estilista uma roupa que conseguisse materializar um sentimento específico para o dia de sua festa, o de se sentir princesa.

Já ao falar sobre custos, Sofia se limitou a dizer que seu vestido "custou a metade" dos quase $\mathrm{R} \$ 90$ mil reais que tinha proposto Sandro Barros, outro estilista famoso, no primeiro atendimento que buscou na capital paulista. Desembolsando então cerca de $\mathrm{R} \$ 45 \mathrm{mil}$ em seu vestido de noiva Lethicia Bronstein, além dos custos das cinco viagens a São Paulo no período de provas e para buscar a peça pronta, nenhuma economia foi feita para ter aquilo que ela considerava como o item mais importante do casamento. "[A noiva] é o personagem principal da noite $e$ as pessoas esperam que ela esteja deslumbrante", me dizia para argumentar que é do vestido que as pessoas mais se lembrariam depois do casamento. Segundo ela, nem a decoração e nem a comida - itens geralmente bastante 
onerosos nas festas - produziriam o mesmo impacto de aprovação ou reprovação causado pelo vestido da "personagem principal". Além disso, contou de um casamento ocorrido na cidade, com decoração elaborada e banda famosa, mas "o vestido tava horroroso, acabou com o casamento" e que "todas as fotos vão estar feias, porque a noiva tava feia".

Antes da festa de Sofia acontecer, as profissionais de decoração, cerimonial e maquiagem contratadas já divulgavam fotos dos preparativos do evento que reuniu quinhentas pessoas na igreja mais disputada e no salão de festas mais caro da cidade. $\mathrm{O}$ casamento dela com um dos maiores herdeiros do setor varejista de Belém, amigo de seu irmão mais velho, mobilizou atenção especial naquela noite de junho. Mas, para ela, o fato de seu vestido ser confeccionado por uma estilista notória de São Paulo foi o motivo de maior expectativa.

A noiva relembrou que "teve gente que se escondeu, foi pra Basílica [onde ocorria a cerimônia religiosa], ficou na porta só pra ver o vestido" e me chamou atenção ao número de visualizações que o vídeo de transformação de seu vestido "de princesa" em vestido "de festa" obteve em uma rede social: "modéstia à parte, eu acho que meu vestido foi um dos mais bonitos que já teve aqui nessa cidade", considerava. E quando eu perguntei o que a fez ir até São Paulo para buscar seu vestido, ao invés de confeccionar um em Belém, ela foi contundente: "não confio nas profissionais daqui", referindo-se a sua cidade natal.

Uma avaliação ruim das profissionais do extremo leste da cidade São Paulo também foi o que levou Gabriela a procurar seu vestido longe de casa. Reclamando da qualidade das peças alugadas pelo noivo e padrinhos nas lojas de São Mateus, onde eu fazia trabalho de campo, ela contava que o atendimento recebido na loja do centro em nada parecia com aquele que ela recebeu na loja de seu bairro. Lembrou que as calças dos padrinhos tinham sido entregues inacabadas, que o terno do noivo parecia ter uma costura frouxa e, principalmente, que foi atendida com descaso pelas funcionárias em São Mateus. 
Cruzando vinte e cinco quilômetros, nove estações de metrô e mais meia hora de ônibus da zona leste até o centro da capital, a noiva desembolsou $\mathrm{R} \$ 2,5$ mil pelo aluguel em uma loja da Rua São Caetano, conhecida também como "Rua das Noivas", e fez do seu vestido o item mais dispendioso de sua festa de casamento. E, embora ela mesma recusasse a dizê-lo "caro" nas provocações do noivo, com efeito, seu traje representava quase $15 \%$ do total gasto em sua festa de $\mathrm{R} \$ 20$ mil. Proporção essa igual aos gastos de Sofia, em Belém, que reservou os mesmos $15 \%$ do valor total de $\mathrm{R} \$ 300$ mil de sua festa para a compra do vestido dos seus sonhos.

Já Camila, do centro de São Paulo, resolveu fazer o contrário e pagou apenas $\mathrm{R} \$ 500 \mathrm{em}$ seu vestido, importado via internet, de uma confecção chinesa. A ideia era mesmo economizar. Dificilmente ela encontraria um aluguel de vestido de noiva com esse valor, muito menos um vestido novo disponível para compra. Camila descobriu o website de vendas de vestido em uma busca online. Selecionou uma fornecedora, visitou seu catálogo de modelos e descreveu o momento de escolha do vestido com uma emoção semelhante àquela relatada por Gabriela ou vista em Helena, mas sem "esse momento suntuoso que todo mundo fala, esse momento glamour...".

Em seguida, com a ajuda de uma amiga de trabalho, tirou as medidas de seu corpo e enviou para o website, que ainda fez as traduções para o mandarim. Ela conta que a escolha do vestido foi uma das primeiras coisas que resolveu mobilizar quando decidiu se casar. Já que o item viria de longe, a chegada da encomenda via container marítimo poderia atrasar mais que o previsto ou, pior, vir uma peça que não agradasse muito quando ela experimentasse. Nenhum dos dois problemas aconteceu: o vestido chegou, serviu e ela gostou. Mas sua escolha não agradou muito quem estava ao seu redor.

Enquanto todas as noivas vão $e$ experimentam $e$ todo mundo chora "ai, que lindo, você é a pessoa mais linda do universo!", minha mãe olhou e falou: "ai, não sei”. E ela 
não deixou eu me ver, eu não tinha espelho na minha casa. Eu coloquei, ela não gostou, eu só conseguia me ver assim olhando pra baixo. Ela falou que não gostou, não sei o quê, que tava largo, que não sabia, que tava muito simples... $\mathrm{E}$ ela acabou comigo. Eu me senti a pior pessoa do universo, mas eu tinha gostado do vestido. (...) Aí ela "parece que você tá com um vestido de outra pessoa, que não foi feito pra você. Não, eu te dou os cinco mil reais, se o problema é os cinco mil reais; eu te dou, você vai lá e aluga". E eu estava com meu vestido e eu estava feliz com meu vestido. Mas ela deixou nítido que ela não tinha gostado do vestido. Mas ela não tava vendo com o enchimento, ela não tava vendo com uma luz de uma loja, nada daquilo. E eu queria pelo menos me ver pelo celular, pedi pra ela tirar uma foto pra me ver e ela "não, que você vai divulgar para as pessoas". Então foi um stress muito grande (Camila, São Paulo, 2016).

No ambiente de trabalho a informação do vestido comprado via internet da China também não foi muito aprovada. Camila, que faz parte da administração de um shopping, conta que depressa a notícia se espalhou $e$ iniciaram os "murmúrios na empresa". Colegas vinham comentar sobre a compra em tom de piadas, riam surpresos pela escolha e ela percebia muita ironia em suas falas. Em um primeiro momento chegou até a pensar que o desconforto causado por sua escolha se dava pelo fato de ter comprado um vestido sem nunca ter experimentado. Ela não tinha nem ao menos ido a alguma loja provar os diferentes modelos possíveis de vestidos para se decidir quais estilos buscar. Mas depois ponderou que o motivo do stress era outro: "tô comprando da China e a China pra muitas pessoas aqui é uma coisa negativa". E quando a questionei então sobre o porquê de um vestido da China incomodar tanto, a noiva foi enfática: "porque era barato". 


\section{Vestida para casar}

O vestido é uma prioridade da noiva. Ou ao menos deveria ser. Camila descobriu essa regra quando optou por comprar um vestido via internet, da China e, portanto, barato. Sua mãe e seus colegas de trabalho trataram logo de mostrar que algo estava sendo posto fora de lugar e mostraram também que, embora festas intentem de modo geral ser momentos de conformação de uma narrativa de coesão (Chaves, 2003), os momento de organização que as antecedem são de fato marcados por intensos processos de tensão e conflito nas relações.

"Faltou a vendedora", avaliava Camila na tentativa de compreender o porquê de sua mãe ter rejeitado seu vestido de noiva. A compra, via internet e sem ter passado por alguma loja de vestidos para antecipar a prova do modelo escolhido, parecia ter suprimido um passo do processo de organização da festa. Tinha faltado aquele "momento suntuoso que todo mundo fala, esse momento glamour" prescrito no tempo do casamento.

Sofia, de noiva a agora estilista, se compara à fada madrinha de Cinderela para descrever o ofício de "consolidar sentimentos" de suas clientes. A noiva queria se "sentir princesa" $e$, não aleatoriamente, descreve o espaço de atendimento de Lethicia Bronstein (a estilista escolhida) a partir dos mesmos referenciais. Conta que a sala parecia uma "casinha de boneca", uma "sala de princesa", com corações, coroas e uma "poltrona de rainha" compondo a decoração do ambiente, além das fotos de "celebridades vestindo os vestidos dela".

O estilista que atende Helena faz como a funcionária da loja que alugou o vestido de Gabriela: paramenta a noiva em questão de minutos certificando-se de que nenhum acessório dessa grande fantasia falte no momento de se fechar o negócio. Véus, buquês, penteados improvisados, coroas e até uma sonoplastia ajudam a montar - e emocionar - a noiva de frente aos espelhos iluminados dos provadores das lojas. Esses pareciam ser os elementos que, performatizados, disparavam as sensações então buscadas pelas noivas clientes: ora se sentir "princesa", ora "sereia". 
Divididos a partir de uma lógica de oposição em todos os contextos que circulei durante a pesquisa, os vestidos de noivas oscilam entre duas possibilidades de modelagem e confecção. "Princesas", de modo geral, são chamados aqueles vestidos que seguem justos até a cintura, depois contam com uma saia rodada e armada por camadas de enchimentos (compostos apenas de tecidos ou por estruturas de metal em formatos cilíndricos). Já "sereias" são aquelas peças que investem mais no contorno do corpo e mantêm-se justas até as coxas, para só a partir dos joelhos abrirem-se, geralmente em formato de uma cauda.

Enquanto eu circulava entre noivas e lojas de vestidos voltados para este público, pude levantar um conjunto de referenciais e adjetivos usados para classificar as roupas nesses dois grupos distintos. Helena chegou à loja falando que queria um modelo "clássico" e, como resposta ao pedido, recebeu inúmeros modelos no estilo "princesa". Todos justos no busto e com saias rodadas a partir da cintura. O que mudava de um para outro eram as variações de decotes e combinações de rendas somadas à peça - tampando mais ou menos a pele.

O desejo de se sentir "clássica" ao mesmo tempo que invocava curiosidade do estilista, era por ele também acionado positivamente de modo a favorecer o aluguel do traje: "imagina essa manga longa aí na foto colocando a aliança, aparece o preto e branco da roupa do noivo e a renda branca da noiva, fica lindo", dizia enquanto deslizava a mão pelo véu longo e suntuoso que descia da coroa. A mãe da noiva não escondia a predileção ao modelo de vestido que ela classificava como algo que "parecia uma menininha" e também não escondeu a frustração quando a filha optou pelo modelo contrário, aquilo que momentos antes ela tinha classificado como um estilo de "mulheres que casam com os velhos e querem dar golpe do baú" - uma referência altamente pejorativa sobre um modelo de relação no qual atributos 
femininos de beleza e juventude são intercambiados por favores econômicos masculinos. ${ }^{9}$

A noção de "piriguete" e a imagem da funkeira Valesca Popozuda foram usadas de modo a desqualificar o estilo de vestido que evidenciava e enfatizava as curvas corporais da noiva. Eram os recursos linguísticos usados para atribuir ao modelo "sereia" um valor moral específico, e negativo. Sofia também se casou com um vestido que era ajustado em seu quadril $e$ demarcava o contorno de todo seu corpo, mas o busto e os braços completamente "fechados" com renda a faziam classificar seu modelo como "princesa". Deslocando a ideia de um "vestido princesa" para um modelo que, embora justo, cobria toda sua pele, a noiva ressaltava que a sensação buscada era de uma imagem de sobriedade, em oposição à sensualidade. Seu noivo colaborou na escolha da peça e, quando afirmava que a queria "noiva" e não "sensual" na igreja, acionava noções parecidas com aquelas aludidas pela mãe de Helena.

Helena se vestiu de "sereia" e tratou de desqualificar o vestido de "princesa" dizendo que não queria parecer uma "santa". Reorientou todas as buscas de vestido e elegeu a modelagem mais justa - e sensual - como aquela que a fazia esquecer das acusações de estar acima do peso e a transformava em "bonita", "elegante" e "poderosa". Já Gabriela, que não nomeou seu estilo, causou uma aversão de seu sogro, religioso, ao chegar na cerimônia com um vestido que expunha parte dos seios dentro do decote apertado.

Fosse pelos contornos do quadril ou pela valorização dos seios, os vestidos podiam colocar em evidência outras dimensões de feminilidade que nem sempre uma noiva gostaria de destacar ou que os vestidos "princesas" pareciam esconder. A noiva "menininha" e "santa" deu lugar à noiva sensual e "poderosa" no reflexo do espelho de Helena. Para ela, embora à revelia de sua

\footnotetext{
${ }^{9}$ Um tipo de relação mais detidamente analisado na pesquisa sobre a interação entre o mercado do sexo e o casamento, de Adriana Piscitelli (2013).
} 
mãe, sensualidade e poder caminhariam lado a lado naquilo que ela elegeu como sua performance particular de noiva: se a escolha do vestido era a possibilidade de materialização de um sentimento e de uma personagem assumida no dia do casamento, como dizia Sofia, Helena era a noiva poderosa porque sexy ou sexy porque poderosa.

Ao mesmo tempo, montada sob um modelo todo marcado em seu corpo, a noiva não era indiferente à avaliação externa $e$ procurava outros elementos de negociação moral que pudessem provocar uma conciliação entre seu vestido e sua mãe. "A Valesca Popozuda não usaria o de renda chantilly francesa" repetia aquilo que, para ela, era uma justificativa capaz de afastar o indício de "vulgaridade" do vestido eleito. Seu argumento, nesse sentido, parecia se utilizar de uma ideia comum àquela de Sofia, quando a noiva dizia que "não tem nada mais feminino que renda" para justificar os materiais usados na composição da sua personagemnoiva-princesa em Belém. De um caso a outro, o tecido específico - renda - servia de sinal diacrítico para inscrição de uma feminilidade valorizada e idealizada nos vestidos.

Enquanto Sofia surpreende as amigas ao eleger um vestido que ofuscava sua sensualidade, Helena e Gabriela tencionaram os limites da exposição do corpo de uma noiva. Helena realçou suas curvas ao expor o contorno do seu quadril, já Gabriela encarou a cerimônia com o peito semi-descoberto. Ambas foram alvos de comentários ou tentativas de constrangimento e, para a análise, apontam mais uma convenção disputada no processo de organização de um casamento: há limites para a sensualidade da noiva.

Todas as interlocutoras vinham de contextos econômicos bastante distintos e consumiam vestidos com valores também contrastivos. Mas mesmo que um vestido fosse comercializado por dois, outro por quarenta mil reais, eles eram objetos que podiam tanto criar como apaziguar negociações sobre os limites da sensualidade da "personagem principal". Sofia, casando-se com um homem mais velho e mais rico, talvez não por coincidência foi a única das minhas interlocutoras que teve uma preocupação 
exacerbada em não estar sensual - receio compartilhado com o próprio noivo que não a queria "sensual na igreja". Talvez fosse ela aquela que corresse um risco de cair no filtro moral da "mulher que casa com homem mais velho para dar golpe do baú", sugerido pela mãe de Helena e, nesse sentido, seu vestido podia confrontar tal narrativa. Ela, que não se diz romântica, se produziu como uma "princesa" na cerimônia de casamento. ${ }^{10}$ Por isso, aos olhos surpresos de todos os outros, percorreu "fechada" e "sóbria" os quarenta metros de passadeira da igreja.

Entre "princesas" e "sereias", os modelos de vestidos pareciam fornecer uma possibilidade de as noivas organizarem sentimentos e expectativas sobre uma determinada experiência. Os limites sobre a modulação e exposição do corpo, fosse pela criação de um efeito sensualizado ou seu contrário, eram negociados pelas clientes de modo a produzir diferentes versões de feminilidade. Tal como em outros contextos etnográficos (França, 2010; Facchini, 2008), o estilo das roupas parecia se constituir como um mecanismo de diferenciação e de expressão de contornos de gênero.

Todavia, ao mesmo tempo que as modelagens dos vestidos podiam ser acionadas como operadoras de diferenciação entre feminilidades mais ou menos valorizadas segundo as convenções das minhas interlocutoras, elas podiam também ser usadas como

\footnotetext{
${ }^{10}$ Os termos "princesa" e "romântico" aparecem correlacionados na fala da interlocutora de modo a se aproximar das mesmas concepções que encontrei, anos antes, em minha pesquisa com crianças pequenas (Escoura, 2012). Ela é a mesma noiva que se refere explicitamente ao filme "Cinderela", cujo mote é a realização do amor romântico como forma de salvamento do flagelo da vida cotidiana $e$ foi objeto da pesquisa anterior. Entre as crianças, os termos "princesa" e "noiva" por vezes se confundiam para descrever um contorno de feminilidade considerado ideal. A interlocutora, aqui, parece apontar para novas possibilidades interpretativas quando, ademais, soma os termos "moderna", "atual", "durona", "resolvida" e "prática" para se contrapor às ideias tanto de "princesa" como de "romântica". Esse alargamento de referências parece abrir novas possibilidades de análise para além daquelas já colocadas na pesquisa de 2012.
} 
dispositivos para alargar essas mesmas convenções. Sofia queria se diferenciar de qualquer leitura sensualizada de sua performance como noiva. Helena, por outro lado, parecia querer alargar as convenções sobre o que é ser noiva: tinha renda, tinha véu $e$ vestido branco, mas também tinha muita sensualidade em seu momento de "glamour".

A etapa de escolha dos vestidos era encarada, tanto naquela que acompanhei como nas relatadas, como um instante capaz de oferecer uma prévia das sensações desejadas para o dia do casamento. "Noiva é foto, noiva é estilo", enfatizava o estilista da loja de São Paulo ao justificar para a cliente que sua escolha devia estar orientada pelo critério de "como você quer se ver na foto do seu casamento 10 anos depois". O vestido deveria ser a materialização da imagem como cada noiva queria se ver no espelho ou nas fotografias do evento, numa lógica em que vestido e noiva pareciam se confundir como personagens centrais de um evento previsto como único na vida delas, tal como enfatizava Sofia.

Assim como indicado por Cristina Teixeira Marins (2016) enquanto esteve em campo com cerimonialistas, sob a justificativa do casamento ser uma celebração que ocorre apenas uma vez na vida, os profissionais desse segmento utilizam o fator da extraordinariedade como arma para a negociação de seus serviços. "O céu é o limite" quando se fala em consumo para festas de casamento pois, para eles, é uma possibilidade única de ruptura da ordinariedade da vida cotidiana.

"Dificilmente a noiva casa do jeito que ela é no dia-a-dia", dizia a noiva-estilista de Belém ao defender que o consumo do vestido ultrapassava a expressão de uma identidade (Gell, 2008), mas consolidava sua personagem. De forma particular, uma espécie de dimensão lúdica é criada ao redor desses eventos de modo a construir uma narrativa de outra ordem, na qual um universo idealizado de fadas ou Barbies pode ganhar uma materialidade até então inalcançável quando posto no plano do cotidiano. Ser noiva é, nesse sentido, ser a atriz principal de uma 
grande performance posta às vistas de todos e iniciada já dentro dos provadores das lojas de trajes de festas.

Quando um estilista traz um vestido que, sabidamente, está acima do preço indicado pela cliente, para ser provado, ele de algum modo busca tensionar as fronteiras econômicas compactuadas e se utiliza dos dois lados que a mesma moeda da extraordinariedade pode ter: é glamour e é sacrifício. "Quanto você quer pagar pelo seu sonho?", o bartender dizia ao negociar em uma feira de noivas na capital paulista. E ao final das negociações, sonhos são comprados em longas parcelas no cartão de crédito.

Sob a lógica do sacrifício, Helena aceita o desafio de ficar durante horas debaixo de uma roupa estruturada com ferro para demarcar sua cintura. É o outro preço, somado ao valor do vestido, que irá permitir que ela esteja "deslumbrante" no dia do seu casamento. E é ela também que recorre ao cartão de crédito como forma de driblar o custo do vestido que sai mais caro que o planejado. Mas mais do que o endividamento servir como estratégia para vestir o vestido de rendas francesas em sua cerimônia, parecia que Helena estava apenas seguindo à risca uma norma já enunciada nos preparativos das festas de Gabriela e Sofia e evidenciado pelo constrangimento do vestido chinês de Camila: em vestido de noiva não se economiza.

Nem tempo, nem dinheiro, engajamento ou expectativa podem ser poupados quando noivas estão em busca de seus vestidos. Independentemente de qual o custo total de uma festa, se ela é feita por uma funcionária de shopping ou por um herdeiro do setor varejista, a expectativa é de que o vestido da noiva seja um item valioso.

Tanto Sofia, a noiva de Belém com casamento orçado em $\mathrm{R} \$ 300$ mil, como Gabriela, do casamento de $\mathrm{R} \$ 20$ mil na zona leste de São Paulo, gastam em torno de $15 \%$ do valor total do evento para estarem com os vestidos que desejaram. Mas além da coincidência no percentual dispendido na peça, são as duas também que vão em busca de vestidos produzidos $e$ comercializados longe de casa para compor suas performances de 
noiva. Uma vai da margem geográfica ao centro do município de São Paulo e outra vai do norte do país para a capital paulista em uma busca que acrescenta mais do que quilometragem aos seus trajes.

A "falta de confiança nas profissionais" de seus bairros ou cidades é, em ambos os casos, o argumento que justifica os deslocamentos pela cidade ou entre as cidades. Gabriela compara o atendimento da loja da Rua das Noivas com o de São Mateus para enfatizar a desaprovação dos serviços oferecidos no seu bairro. Sofia, por sua vez, diz não confiar nas profissionais de Belém e, quando fala da estilista de São Paulo, ressalta a qualidade de seu trabalho avaliando que ela deve ter uma "pequena fortuna em materiais".

Quando uma noiva entra com seu vestido em uma cerimônia de casamento, os custos da peça dificilmente são conhecidos pelos convidados. Nas entrevistas, a pergunta sobre os valores gastos nas festas nunca causou constrangimento quando as respostas giravam em torno dos itens em que os casais tinham feito alguma economia. Entretanto, falar sobre os custos de um vestido na maioria dos casos gerava algum tipo de desconforto. Em vestido não se economiza, mas dar indícios de que a compra ou o aluguel foi um exagero capaz de configurar o negócio como uma ostentação é um risco que as noivas não querem correr.

Gabriela rebate seu noivo quando ele acusa que seu vestido foi "caro" e minimiza que "R $\$ 2,5$ mil, foi super barato". Já Sofia fala do valor de seu vestido de maneira indireta, em contraposição ao modelo proposto por outro estilista e por ela recusado. Essa contradição entre convenções que de um lado não permite racionalidade financeira no quesito vestido de noiva $e$, por outro, condena práticas de consumo ostensivas, acaba por colocar as noivas em um complexo limiar. Como afastar o risco de parecer uma consumidora descontrolada e, ao mesmo tempo, suprir as expectativas por um vestido "deslumbrante"? 
Parecia que trazer para Belém um vestido de São Paulo ou do centro para um bairro da "quebrada" 11 era uma estratégia. Trazer um vestido "de fora" configurava uma outra forma de atribuir valor àquele que, por pressuposto, deveria ser um item valioso. $\mathrm{O}$ vestido, nesse sentido, parecia poder absorver o status de um determinado território e evocar, paralelamente, uma nova métrica de valor que não envolvesse, necessariamente, o referencial das cifras de dinheiro.

O consenso por trás dessas ações era de que mesmo que ninguém soubesse que tinha custado mais de $\mathrm{R} \$ 45$ mil, um vestido vindo de São Paulo, em Belém, era algo valioso. Já na zona leste da capital paulista, ainda que uma pessoa nunca tivesse entrado em uma loja da Ruas das Noivas, ela poderia supor que lá paga-se mais do que em São Mateus por um traje. O valor do vestido estava posto em outros referenciais, mas que também comunicavam diferenças e distinções econômicas. E embora Gabriela dissesse ter sido incontrolavelmente "escolhida" por seu vestido quando esteve na loja do centro da capital, foi ela, afinal, que escolheu onde se deixaria ser escolhida.

No casamento noticiado pelas redes sociais, Sofia se apresentou com um "vestido Lethicia Bronstein" que levou, segundo ela, curiosos para frente da igreja ou para as publicações no Instagram. Fazer do seu vestido "um dos mais bonitos que já teve aqui nessa cidade" significava também trazê-lo de fora dessa mesma cidade. Ele era excepcional, pois vinha de um lugar em que as coisas são de melhor qualidade ou de maior profissionalismo, segundo a noiva.

\footnotetext{
${ }^{11}$ Algumas autoras utilizariam "periferia" para descrever os locais de realização da pesquisa na zona leste da capital paulista. O termo costuma estar associado não apenas a uma designação geográfica de um território, mas também a uma localização na cartografia econômica. Para uma discussão sobre associação de organização urbana e pobreza, ver Maricato (2013) e Rolnik (1988). Optei, neste trabalho, por utilizar a categoria êmica "quebrada" que, ao lado de "favela", apareceu no meu trabalho de campo na região.
} 
Além disso, em seu caso específico, é preciso notar que quando então falamos de noivas que dispõem de quantias muito altas de dinheiro, cujas escolhas de consumo nem sempre representam sacrifícios de endividamento como de Helena, outros elementos entram nessas táticas de distinção. Sofia traria seu vestido de São Paulo, mas não é de qualquer "São Paulo" que vem o vestido de Sofia.

Embora a Rua das Noivas, onde Gabriela alugou seu traje, seja um importante centro de comercialização de vestidos de noivas na capital paulista, a São Paulo em que Sofia busca sua roupa é aquela onde "muitas fotos de celebridades vestindo os vestidos" de sua estilista enfeitam as paredes da loja. Nesse sentido, ao mesmo tempo que Sofia se diferencia de todas as outras noivas de Belém que não terão os vestidos "mais bonitos da cidade" ou curiosos à sua espera na frente da igreja, ela agencia seu trânsito por São Paulo de modo a se diferenciar também de noivas como Gabriela. Apesar de ambas usarem o trânsito pela cidade como operador de demarcação de diferença, a São Paulo que se apresenta como território de diferenciação para uma noiva não é a mesma para a outra.

Mas também não bastava a um vestido vir de longe para ser considerado automaticamente um vestido melhor; ele tinha que vir de algum território também mais valorizado. Se pensarmos apenas na lógica de deslocamento territorial, certamente o vestido de Camila, vindo da China, seria aquele com a maior distância acumulada em sua trajetória. Entretanto, é justamente pelo fato de ter vindo de lá que ele caiu no desgosto da mãe e dos colegas de trabalho da noiva. A valorização do vestido não se dava apenas pelo cálculo da distância em si, mas pelo valor ou distinção do território que o comercializou. ${ }^{12}$ Se as noivas acionavam noções

\footnotetext{
${ }^{12}$ No corpo completo da tese em elaboração, discuto mais detalhadamente a diferença entre a produção $e$ a comercialização do vestido no processo de atribuição de seu valor. Em resumo, aponto que estando sob constante disputa entre os profissionais do mercado, as técnicas e os materiais envolvidos na composição das roupas parecem ser menos determinantes na configuração do
} 
de diferenciação em seus trânsitos pelos territórios, era porque havia também hierarquia entre os diferentes lugares por onde circulavam. ${ }^{13}$

\section{Considerações finais e o vestido que faz uma noiva de valor}

Ao comparar três diferentes festas voltadas ao público de homens homossexuais em São Paulo, a pesquisa de França (2010) indicou que além de diferenças entre práticas de consumo nos lugares, o consumo do próprio lugar produzia diferenciações entre corpos e identificações. Da relação entre as "cenas" e os espaços, o consumo compunha estilos, subjetividades e posicionamentos entre os sujeitos. Consequentemente, em paralelo aos processos de hierarquização dos lugares, sujeitos também se hierarquizavam pelo consumo dos lugares.

Entre noivas, um vestido vindo de longe poderia provocar uma curiosidade e um reconhecimento de que ele seria um objeto mais especial, mas a valorização do traje não se daria apenas pelo cálculo da distância em si, e sim pelo valor ou distinção do território de onde ele viria. Assim, perseguindo um vestido de valor pelos diferentes lugares de comercialização, o trânsito de noivas conformava hierarquias também entre elas.

Ao mesmo tempo em que o contexto de comercialização de um vestido, como vimos na seção anterior, era a referência para configurar o seu valor e atestar que aquele era um objeto valioso, deslocar-se pela cidade e entre as cidades nos diferentes territórios

preço do vestido do que a composição espacial e performática dos atendimentos - aquilo que é, afinal, objeto de avaliação concreta das clientes.

${ }^{13}$ Por essa mesma chave de oposição entre centro versus "quebrada" ou São Paulo versus Belém, poderia ser somada também a desvalorização da China em contrapartida aos vestidos nacionais ou materiais vindos de outros países. Helena tentou convencer sua mãe de que estava fazendo uma boa escolha com o argumento da renda que era, pois, francesa. Mas a internacionalidade do vestido de Camila, em contraponto, não significava nenhuma valorização. 
de venda e aluguel dos trajes era uma estratégia utilizada pelas clientes para se constituírem enquanto uma noiva de valor.

Gell (1998), em seu debate com a antropologia da arte, defende que os objetos são ao mesmo tempo produto $e$ produtores de relações, dotados de uma agência intencionalmente voltada à inscrição do mundo em sua volta. Gabriela, a noiva de São Mateus, parecia notar a capacidade de agência de seu traje quando avaliou que "não é a gente que escolhe o vestido, é o vestido que escolhe a gente". Mesmo que suja e a princípio pouco atrativa, a peça ganhou vida quando entrou em contato com seu corpo e transformou Gabriela em uma noiva.

Já analisando o mercado de gado de elite, um produto de acesso restrito, portanto, de luxo e com paralelos muito próximos ao que identificamos no mercado de vestidos de noivas, Leal (2016) discorre sobre a produção de valor a partir da relação entre homens e animais. No triângulo mineiro, criadores de zebu formataram um processo de racialização bovina, controlaram genealogias e definiram pedigrees a partir de seus próprios espécimes, produzindo suas reses enquanto "gado de elite" e a si, consequentemente, enquanto elite: saber produzir gado com distinção é também se produzir como distinto. Inspirada em Appadurai (2008), a autora analisa o intercâmbio de biografias entre bois e criadores para apontar que, além da circulação de materiais genéticos de prestigiados raçadores bovinos, a reputação e o prestígio dos criadores também estavam sob disputa nas negociações dos leilões gado de elite.

Da relação entre profissionais com vestidos, noivas com profissionais $e$ vestidos com noivas, reputações e prestígios circulavam pelas lojas de trajes de festa e compunham uma complexa cartografia da distinção. Vestir-se de noiva e, sem modéstia, ser a "mais bonita da cidade" era um projeto no qual parecia haver alguma possibilidade de experimentar uma sensação de ascensão, ainda que extraordinária, ou conflituosa. Para tanto, nenhuma economia poderia ser feita e nenhum sacrifício evitado. 
Fosse pelo acúmulo de dívidas ou colocando seus corpos em longas jornadas de busca pelo modelo ideal, a escolha do vestido de noiva aparecia como uma etapa fundamental de um projeto de distinção. Tensionando narrativas sobre contornos valorizados de feminilidade, negociando referenciais de distinção econômica e sob o risco de ter sua reputação ou a de sua festa ameaçada, as noivas iam criando conexões entre si e os vestidos oferecidos pelo mercado.

Enquanto não existe noiva sem vestido, é o vestido que produz a noiva. Da circulação de modelos "princesas" e "sereias" se costuravam estilos hierarquizados de gênero, ao mesmo tempo em que da circulação de vestidos e noivas entre as lojas se produziam reputações e prestígios pelos territórios do mercado. Assim, valores de vestidos e noivas de valor iam sendo mutuamente constituídos e distinçóes se delineavam num processo no qual para se tornar uma noiva de valor era preciso, antes, conquistar um vestido de valor.

\section{Referências bibliográficas}

APPADURAI, Arjun. A vida social das coisas: as mercadorias sob uma perspectiva cultural. Rio de Janeiro, Eduff, 2008.

CHAVES, Christine de Alencar. Festas da Politica: uma etnografia da modernidade no sertão (Buritis - MG). Rio de Janeiro, Relume Dumará, Núcleo de Antropologia da Política/Ufrj, 2003.

EsCOURA, Michele. Girando entre Princesas: performances e contornos de gênero em uma etnografia com crianças. Dissertação (Mestrado em Antropologia), Universidade de São Paulo, SP, 2012.

. Formal attire from one side of the "bridge" to the other: the wedding market and class and gender relations inscribed in the territory of the city. Vibrant. Virtual Brazilian Anthropology, Brasilia, vol.14, $n^{\circ} 3$, 2017 [http://www.scielo.br/scielo.php?script=sci_arttext\&pid =S180943412017000300600\&lng=en\&nrm =iso - acesso em 22 mai 2018]. 
FACCHINI, Regina. Entre Umas e Outras: mulheres, (homo)sexualidades e diferenças na cidade de São Paulo. Tese (Doutorado em Ciências Sociais), Unicamp, Campinas-SP, 2008.

FRANÇA, Isadora. Consumindo lugares, consumindo nos lugares: homossexualidade, consumo e subjetividades na cidade de São Paulo. Tese (Doutorado em Ciências Sociais), Unicamp, Campinas, SP, 2010.

Gell, Alfred. Art and Agency. Oxford, Oxford University Press, 1998.

- Recém-chegados ao mundo dos bens: o consumo entre os Gonde Muria. In: APPADURAI, Arjun (org). A vida social das coisas: as mercadorias sob uma perspectiva cultural. Rio de Janeiro, Eduff, 2008, pp.143- 178.

LEAL, Natacha. Nome aos bois: zebus e zebuzeiros em uma pecuária brasileira de elite. São Paulo, Hucited; Anpocs, 2016.

MARICATO, Ermínia. É a questão urbana, estúpido! In: MARICATO, E. et alii. Cidades rebeldes: Passe Livre e as Manifestações que tomaram as ruas do Brasil. São Paulo, Boitempo, Carta Maior, 2013, pp.19-26.

MARINS, Cristina Teixeira. Quando o céu é o limite: um olhar antropológico sobre o universo dos casamentos e dos cerimonialistas. Niterói, Eduff, 2016.

MILLER, Daniel. Teoria das compras. São Paulo, Exame, 2000.

PISCITELli, Adriana. Trânsitos: brasileiras nos mercados transnacionais do sexo. Rio de Janeiro, Eduerj, 2013.

RoLNIK, Raquel. São Paulo, início da industrialização: o espaço é político. In: KowARICK, Lúcio (Org.). As Lutas Sociais e a Cidade. São Paulo, Paz e Terra / UNRISD, 1988, pp.207-245. 